\title{
SISTEM PENGOLAHAN DATA JAMAAH UMROH BERBASIS WEB MENGGUNAKAN METODE INTERPOLATION SEACRH PADA PT. KAISA ROSSIE SEMARANG
}

\author{
Eko Siswanto ${ }^{1}$, Arif Iskandar ${ }^{2}$, Syamsul Ma'arif ${ }^{3}$ \\ ${ }^{1}$ Program Studi Sistem Informasi, STIMIK Pro Visi Semarang \\ ekosiswanto@prvisi.ac.id \\ ${ }^{2}$ Program Studi Manajemen Informatika, STEKOM Semarang \\ aripdevel@gmail.com \\ ${ }^{3}$ Program Studi Sistem Informasi, UNISNU Jepara \\ syamsulmaarif@unisnu.ac.id
}

\begin{abstract}
The use of software as a supporting tool to input data in a company is needed. The software that is used of course must also be able to work effectively and efficiently so that it can support the performance of administrative staff. Every company, private institution or government has certainly done a filing process to store files or data that are considered important. Archiving data on pilgrims performed at this company is still centralized in several Microsoft Excel files for all staff staff. Search is needed to find specific information from a table when the exact location of that information was previously unknown. When the array data is ordered with key values, searching data can be useful using method interpolation search for efficient to find a key value from data array. The system development method used in this system is the Research And Development $(R \& D)$ method. This study purpose is intended tobe able to assist the task of the cashier in inputting data and admin in making reports given to the leadership, and information appropriate to the position of the employee.
\end{abstract}

Keywords: design, data, applications, umrah, community

\begin{abstract}
Abstrak
Penggunaan perangkat lunak sebagai sarana pendukung untuk menginput data disebuah perusahaan sangat dibutuhkan. Perangkat lunak yang digunakan tentunya juga harus dapat bekerja dengan baik, sehingga dapat mendukung kinerja pegawai tata usaha. Setiap perusahaan, instansi swasta maupun pemerintahan sudah pasti melakukan proses pengarsipan untuk menyimpan berkasberkas atau data yang dianggap penting. Pengarsipan data jamaah yang dilakukan di perusahaan ini masih terpusat dalam beberapa file Microsoft Excel untuk semua staf karyawan. Pencarian dilakukan untuk mencarisebuah informasiyang tidak diketahui sebelumnya. Dari sebuah larik data yang sudah berurutan dan memiliki key (kunci), pencarian data bisa menggunakam metode interpolation search untuk mengefisiensikan pencarian key (kunci) di dalam sebuah larik data.Dalam membangun sistem pengembangannya, penelitian ini menggunakan metode Research And Develoment (R\&D). Tujuan dari penelitian ini adalah diharapkan dapat membantu tugas kasir dalam penginputan data maupun admin dalam pembuatan laporan yang diberikan kepada pimpinan,dan informasi tepat sesuai dengan jabatan karyawan.
\end{abstract}

Kata kunci: rancang, bangun, aplikasi, data, jamaah, umroh

\section{PENDAHULUAN}

Perusahaan PT. Kaisa Rossie yang beralamat di jalan cendrawasih No.17 C-D Semarang merupakan perusahaan yang bergerak dibidang tour dan travel, di perusahaan ini melayani berbagai jasa seperti jasa umroh dan haji.PT.Kaisa Rossie adalah salah satu anggota dari himpunan muslim penyelenggara umroh dan haji (HIMPUH) yang terdaftar pada kementrian agama dengan nomor SK.MENTERI AGAMA RI NO.D/259th.2010. Perusahaan ini memiliki karyawan sebanyak tiga puluh orang yang terbagi atas beberapa divisi.Dalam pelayanan 
umroh ada delapan orang karyawan yang terdiri atas pendataan, admin, tiket, perlengkapan serta kasir. Sarana dan prasarana di perusahaan ini didukung dengan komputer sebanyak dua puluh lima,sedangkan untuk bagian umroh terdapat delapan komputer.Semua komputer pada PT.Kaisa Rossie sudah terhubung secara Local Area Network (LAN) sehingga komputer dapat bertukar data dengan komputer lain. PT. Kaisa Rossie dapat memberangkatkan jamaah umroh sebanyak tiga kelompok terbang dalam satu bulan atau dengan total minimal dua puluh jamaah umroh dalam rombongan maupun perorangan.Dalam proses registrasi jamaah umroh disediakan pilihan keberangkatan dan batas waktu dalam pelunasan biaya adalah dua minggu sebelum keberangkatan.Pengarsipan data jamaah yang dilakukan di perusahaan ini masih terpusat dalam beberapa file Microsoft Excel untuk semua staf karyawan, sehingga kasir yang ingin menginputan data para calon jamaah yang ingin melakukan proses pelunasan biaya umroh maupun haji setelah pembayaran Down Payment mengalami kesulitan karena kasir harus melalui proses pencarian data per-file dari jamaah kemudian mencari data biaya yang sudah terbayar. Berikut ini beberapa data jamaah umroh reguler maupun jamaah umroh plus.

Untuk memudahkan kasir dalam melakukan penginputan data dibutuhkan sebuah sistem dan metode pencarian data agar kasir dapat melakukan pencarian data yang sesuai dan akurat, dengan demikian proses pembayaran maupun pengecekan data calon jamaah dapat dilakukan dengan efektif.

Pencarian dilakukan dari sebuah data yang sudah tersusun dalam sebuah tabel untuk diketahui informasi yang ada didalamnya. Pencarian data pada dasarnya menyimpan sebuah referensi didalamnya yang secara terorganisir, kelompok data tersebut disebut tabel. Ada beberapa jenis metode dalam pencarian salah satunya adalah metode Interpolation Search. Metode ini akan menggunakan key (kunci) dalam sebuah data yang sudah tersusun dalam larik data, sehingga proses pencarian tidak dilakukan seacara menyeluruh di setiap key yang ada dalam larik data. Sebelum melakukan pencarian dengan metode interpolasi, data yang telah tersimpan haruslah berurutan karena ini menjadi syarat dalam metode Interpolation Search.

\section{TINJAUAN PUSTAKA}

\section{Pencarian}

Menurut (KBBI, 2019) kata pencarian adalah sebuah proses. Dalam bahasa pemrograman,pencarian adalah suatu tindakan untuk mendapatkan data dalam sekumpulan data.

\section{Data}

Menurut (Sutarman, 2012),"Data merupakan sebuah fakta dari sesuatu pernyataan yang berasal dari kenyataan, di mana pernyataan tersebut merupakan hasil pengukuran atau hasil dari sebuah pengamatan. Data dapat berupa angka-angka, huruf-huruf, simbol-simbol khusus, atau gabungan darinya".Data dapat memberikan gambaran tentang suatu keadaan atau persoalan.

Algoritma

Di dalam sebuah program komputer, ada beberapa proses yang mendasar untuk menghasilkan sebuah informasi.Proses atau langkah-langkah dalam memperoleh informasi itu disebut algoritma. Sebagai contoh untuk menghitung gaji karyawan digunakan algoritma yang mengandung dasar operasi matematikan untuk menghasilkan laporan gaji karyawan sesuai urutan yang telah ditentukan sebelumnya,sehingga informasi yang ditampilkan bisa diketahui prosesnya secara terperinci. Oleh karena itu algoritma sangat erat hubungannya dalam sebuah sistem yang akan dibangun. Di beberapa sistem yang mengandung operasi secara runtut dapat juga disebut sabagai algoritma. $\mathrm{Di}$ beberapa daerah seperti amaerika, hukum di negara ini mengizinkan sebuah algoritma menjadi hak paten secara efektif,meski demikian hal itu hanya sebuah perwujudan fisik dengan kemungkinan tersedianya algoritma tersebut. Searching adalah cara pencarian data dengan menelusuri kembali data-data tersebut. Data yang dicari dapat berupa array dalam memory atau bisa juga pada file di externalstorage. Searching sendiri dapat dibagi menjadi 3 , yaitu: 
a. Sequential Search (Linear Search).

Teknik pencarian data dari array yang paling mudah adalah dengan cara sequential search, dimana data dalam array dibaca satu demi satu, diurutkan dari index terkecil ke index terbesar, maupun sebaliknya.

b. Binary search.

Metode pencarian yang kedua adalah binary search, pada metode pencarian ini, data harus diurutkan terlebih dahulu.Pada metode pencarian ini, data dibagi menjadi dua bagian (secara logika), untuk setiap tahap pencarian.

c. Interpolation search.

Interpolation search merupakan salah satu metode pencarian yang dapat digunakan. Metode ini lebih efisien dalam pencarian daripadabeberapa metode Binary yang harus memecah data terlebih dahulu maupun sequential search yang harus mencari data di semua data. Dibanding dengan kedua algoritma sebelumnya, metode interpolation search sangat efektif dalam melakukan pencarian data tanpa menjelajahi setiap elemen dari sebuah data maupun tabel. Dari item yang telah ditemukan dengan metode ini akan memperkirakan sebarapa jauh item itu berada dalam sebuah data dari posisi saat itu dalam pencarian berikutnya, dengan syarat data harus sudah urut dan berada dalam struktur larik data dan seketika itu juga pencarian akan diproses. Rumus umum dalam Interpolation Search sebagai berikut:

$$
\text { posisi }=\frac{k u n c i-k[\min ]}{k[\max ]-k[\min ]} \times(\max -\min )+\min
$$

\section{Gambar 1. Rumus Interpolation Search}

\section{Keterangan}

1. kunci,kunci pencarian.

2. $\mathrm{k}$ [min], nilai record terkecil.

3. $\mathrm{k}[\mathrm{max}]$,nilai record terbesar.

4. max,nilai awal.

5. min, nilai akhir.

Cara kerja metode pencarian interpolasi dapat disimulasikan sebagai berikut, dimisalkan penulis memiliki data terurut seperti di bawah ini:

index konversi
\begin{tabular}{|c|c|l|l|}
\hline$[0]$ & 0 & Aku & Saya \\
\hline$[1]$ & 1 & Bocah & Anak \\
\hline$[2]$ & 2 & Budhal & Berangkat \\
\hline$[3]$ & 3 & Dolan & Main \\
\hline$[4]$ & 4 & Getih & Darah \\
\hline$[5]$ & 5 & Kali & Sungai \\
\hline$[6]$ & 6 & Kanca & Teman \\
\hline$[7]$ & 7 & Kodanan & Kehuianan \\
\hline
\end{tabular}

Gambar 2. Contoh data kumpulan kalimat

Contoh dengan kata kunci pencarian 3:

1 Pencarian data Kunci (konversi)? dengan nilai 3

2 Posisi kunci dapat dicari dengan rumus [index] $=(3-0) /(7-0)^{*}(7-0)+0$, ditemukan bahwa kuncinya bernilai angka 3 .

3 Setelah diketahui posisinya lakukan validasi data apakah kunci 3 adalah kunci yang benar,jika benar tampilkan data yang ditemukan. Dari contoh diatas bahwa kunci 3 adalah informasi yang ada dalam tabel dengan isi dolan dan main untuk dalam Indonesia.

Contoh dengan kata kunci pencarian 9.

1 Pencarian data Kunci (konversi)? dengan nilai 9

2 Posisi kunci dengan menggunakan rumus [index] $=(9-0) /(7-0)^{\star}(7-0)+0$, dan menghasilkan kunci 9

3 Dari kunci 9 kemudian data dicari apakah ada dalam tabel Kode [9,jika tidak ada maka kunci 9 tidak ada dalam tabel.

\section{Definisi PHP}

Pada tahun 1994 seorang programmer bernama Rasmus Lerdorf awalnya membuat sebuah halaman website pribadi, tujuannya adalah untuk mempertahankan halaman website pribadi tersebut sekaligus membangun halaman web yang dinamis. PHP pada awalnya diperkenalkan sebagai singkatan dari Personal Home Page. PHP pertama ditulis menggunakan bahasa Perl (Perl Script), kemudian ditulis ulang menggunakan bahasa pemograman C CGIBIN (Common Gateway Interface-Binary) yang ditujukan untuk mengembangkan halaman website yang mendukung formulir dan penyimpanan data. Pada tahun 1995 PHP Tool 1.0 dirilis untuk umum, kemudian 
pengembangannya dilanjutkan oleh Andi Gutmans dan Zeev Suraski.

Menurut (Sibero, 2011), "PHP adalah pemograman (interpreter) adalah proses penerjemahan baris sumber menjadi kode mesin yang dimengerti komputer secara langsung pada saat baris kode dijalankan".Sedangkan (Anhar, 2010), "PHP singakatan dari Hypertext Preprocessor yaitu bahasa pemograman web server-side yang bersifat open source". Dari kedua pendapat yang dikemukakan oleh beberapa ahli tersebut bahwa dalam pembuatan maupun pengembangan sebuah web yang bersifat statis atau dinamis dapat menggunakan PHP disisi server side yang juga bisa berjalan dengan HTML secara bersamaan.

\section{Definisi MYSQL}

MySQL adalah database server yang awalnya berjalan pada sistem Unix dan Linux.Seiring berjalannya waktudan semakin banyak pengguna yang menggunakannya,MYSQL merilis beberapa platform yang bisa berjalan di beberapa sistem operasi,salah satunya adalah sistem operasi Windows. (Bunafit, 2010).

MYSQL sendiri tergolong dalam Relational Database Management System (RDBMS) yang memiliki lisensi GPL (General Public License ) dan didistribuskan secara gratis. Sehingga semua orang diberi kebebasan mengembangkan atau menggunakan tanpa menjadikan produk maupun turunanya bersifat komersil.Konsep utama MYSQL sendiri berasal dari SQL (Structured Query Language) yang didalam pengoperasian databasenya berfungsi untuk mengolah data yang meliputi pemilihan atau seleksi dan pemasukan data yang bisa dilakukan secara otomatis. Keandalan suatu sistem database (DBMS) dapat diketahui dari cara kerja optimizer-nya dalam melakukan proses perintah-perintah SQL, yang dibuat oleh user maupun program-program aplikasinya. Sebagai database server, keunggulan MYSQL dibanding dengan database server lainnya bisa dilihat dari query data yang bisa dilakukan oleh single user,kecepatan query MySQL bisa sepuluh kali lebih cepat dari Postgre SQL dan lima kali lebih cepat dibandingkan Interbase.

\section{HASIL DAN PEMBAHASAN}

Setelah dilakukan ujicoba lapangan yang melibatkan user / penguna. Berikut adalah produk akhir yang dihasilkan dari hasil pengembangan.

\section{Halaman Login}

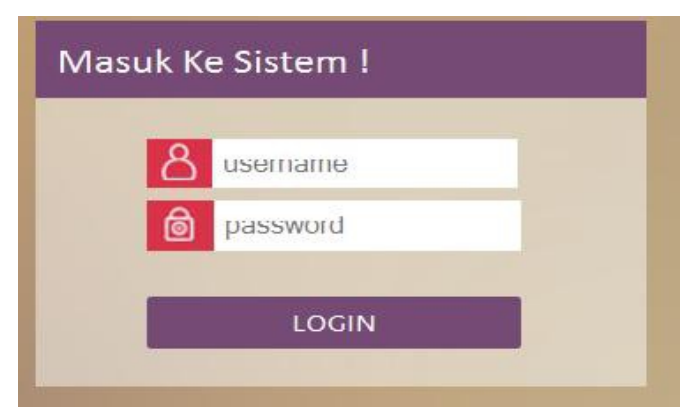

Gambar 3. Menu Utama

Sebelum user / penguna masuk kedalam sistem,makauser / penguna akan melakukan validasi berupa username dan password pada form login untuk masuk kedalam sistem. Jika username dan password ditemukan dan cocok dengan data yang berada di database maka user/penguna akan masuk ke menu utama.

\section{Tampilan Menu Utama}

Setelah user/pengguna berhasil masuk kedalam sistem,maka user/pengguna akan masuk ke menu utama.Ada beberapa tampilan menu utama sesuai dengan kebutuhan informasi user/pengguna.Berikut beberapa tampilan menu utama.

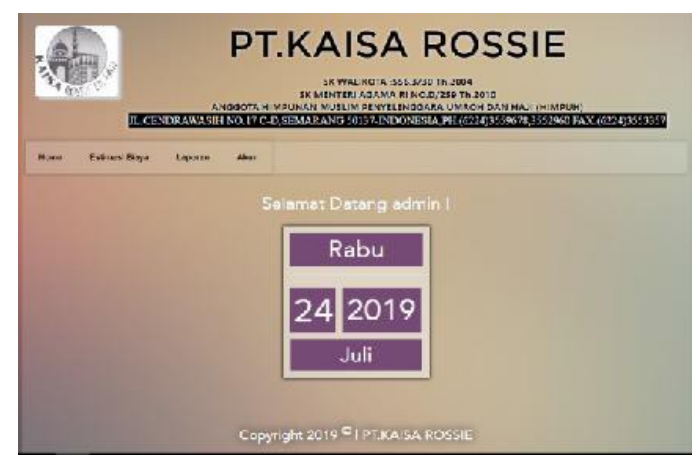

Gambar 4. Tampilan Menu Utama user/pengguna admin 
Keterangan :

Saat user/pengguna masuk sebagai admin maka ada beberapa menu seperti estimasi biaya,user laporan dan akun. Hak akses admin dapat melakukan pembuatan biaya paket umroh melalui menu estimasi biaya,selain itu admin juga bisa melakukan pengelolaan data user/pengguna dan melakukan pengelolaan laporan data jamaah maupun laporan data paket umroh yang akan dicetak untuk kemudian melakukan pengarsipan data.

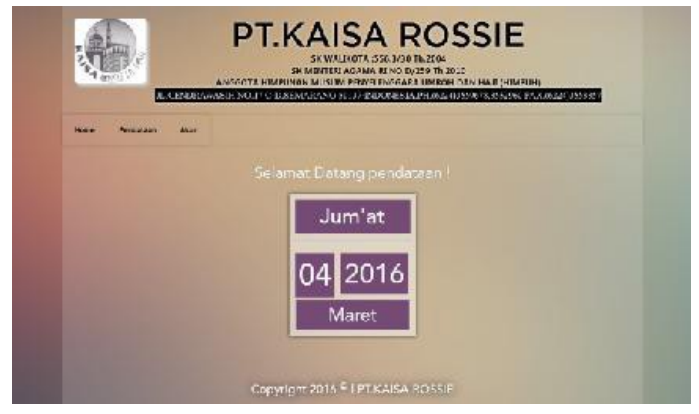

Gambar 5.Tampilan Menu Utama user/pengguna pendataan.

Keterangan :

Saat user/pengguna masuk sebagai pendataan maka ada beberapa menu seperti pendataan dan akun,Hak akses pendataan dapat melakukan pengelolaan data jamaah umroh yang melakukan registrasi.Dan pada menu akun user/pengguna pendataan akan bisa mengganti password.

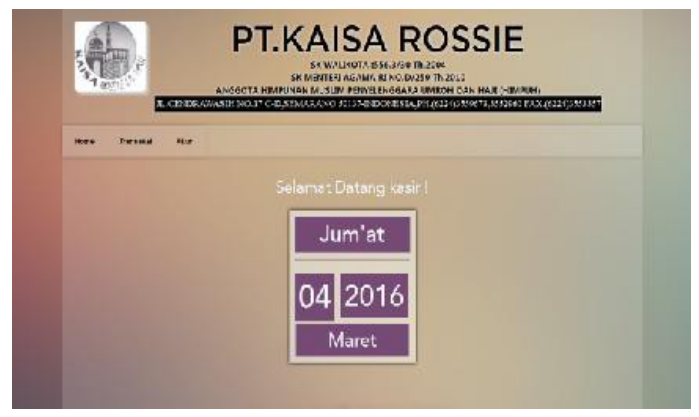

Gambar 6.Tampilan Menu Utama user/pengguna kasir.

Keterangan :

Saat user/pengguna masuk sebagai kasir maka ada beberapa menu seperti transaksi dan akun,Hak akses kasir dapat melakukan pengelolaan data transaksi jamaah umroh yang melakukan pembayaran biaya umroh.Dan pada menu akun user/pengguna pendataan akan bisa mengganti password.

\section{Halaman Ganti Password}

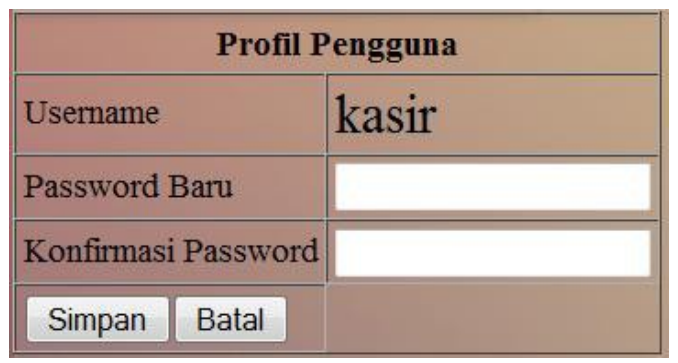

Gambar 7.Tampilan Halaman Ganti Password

Cara Kerja:

1. Tombol simpan untuk menyimpan password yang baru.

2. Tombol Batal untuk kembali ke halaman menu utama.

3. Ketika data password baru dan konfirmasi password tidak sesuai maka akan muncul pesan kesalahan (Password tidak sama!)

\section{Halaman Estimasi Biaya}

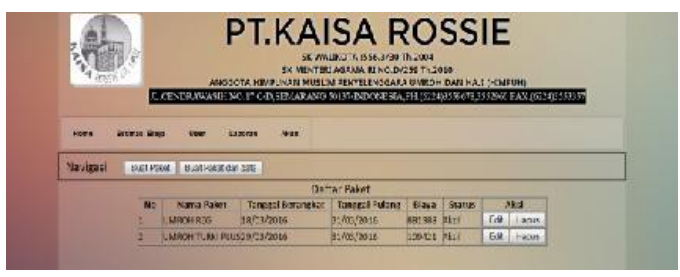

Gambar 8.Tampilan Halaman Estimasi Biaya

Cara Kerja:

1. Tombol buat paket untuk membuat biaya umroh.

2. Tombol Buat Paket dari data untuk membuat biaya umroh dengan data yang sudah ada pada daftar paket,jika tombol ini di klik maka tombol edit pada tabel daftar paket akan berubah menjadi tombol buat dan tombol Buat paket dari data berubah menjadi tombol batal yang berfungsi untuk membatalkan perintal buat paket dari data

3. Tombol Edit akan berfungsi sebagai editing data paket jika ada beberapa kekeliruan data maupun penyesuaian data paket umroh. 
4. Tombol Hapus digunakan untuk menghapus data paket umroh.

\section{Halaman User}

\begin{tabular}{|l|l|l|l|l|}
\hline \multicolumn{5}{|c|}{ Daftar User } \\
\hline No & Username & Akses & Aksi \\
\hline 1 & admin & admin & Edit & Hapus \\
\hline 2 & pendataan & pendataan & Edit & Hapus \\
\hline 3 & kasir & kasir & Edit & Hapus \\
\hline 4 & aman & admin & Edit & Hapus \\
\hline 5 & lukam & pendataan & Edit & Hapus \\
\hline 6 & arif & kasir & Edit & Hapus \\
\hline
\end{tabular}

Gambar 9.Tampilan Halaman User

Cara Kerja:

1. Tombol tambah digunakan untuk menambah user/pengguna.

2. Tombol Edit digunakan untuk mengedit hak akses user/pengguna.

3. Tombol Hapus digunakan untuk menghapus data user/pengguna.

\section{Form User}

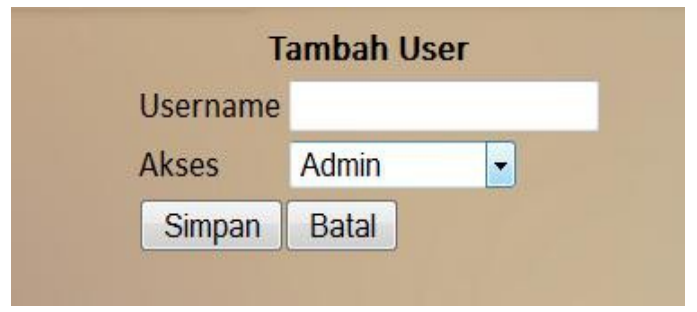

Gambar 10. Tampilan Form User

Cara Kerja:

1. Tombol tambah digunakan untuk menambah user/pengguna.

2. Tombol Simpan digunakan untuk menyimpan data user/pengguna.

3. Tombol Batal digunakan untuk kembali pada halaman user.

\section{Form Estimasi Biaya}

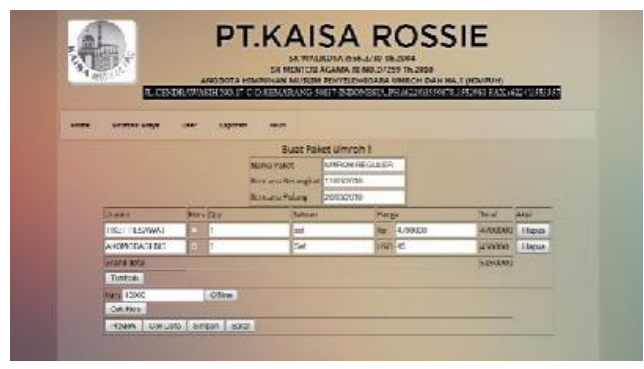

Gambar 11. Tampilan Form Estimasi Biaya

Cara Kerja:

1. Tombol tambah digunakan untuk menambah rincian biaya pada paket umroh.

2. Tombol Hapus digunakan untuk menghapus rincian biaya pada paket umroh.

3. Tombol Offline berfungsi untuk menginput kurs jika komputer tidak terkoneksi jaringan internet.

4. Tombol cek kurs berfungsi untuk mengambil data kurs dari situs web bank BI.

5. Tombol Preview berfungsi untuk menampilkan sementara rincian biaya.

6. Tombol cek data digunakan untuk mengecek apakah field yang berada pada rincian biaya sudah lengkap,jika kurang lengkap input akan berwarna merah.

7. Tombol Simpan digunakan untuk menyimpan biaya paket umroh.

8. Tombol Batal digunakan untuk kembali ke menu estimasi biaya.

\section{Form Data Jamaah}

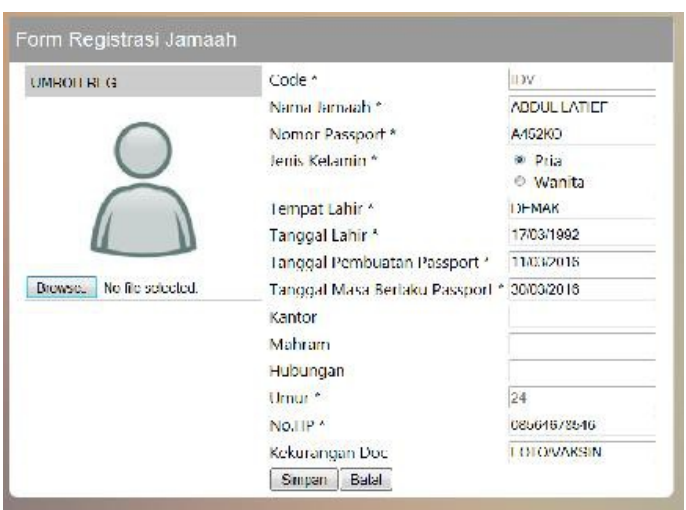

Gambar 12. Form registrasi Jamaah 
Cara Kerja:

1. Tombol simpan digunakan untuk menyimpan data jamaah.

2. Tombol browse digunakan untuk mengambil data foto jamaah dari disk komputer.

3. Tombol Batal digunakan untuk kembali ke halaman isi data.

\section{Halaman isi data}

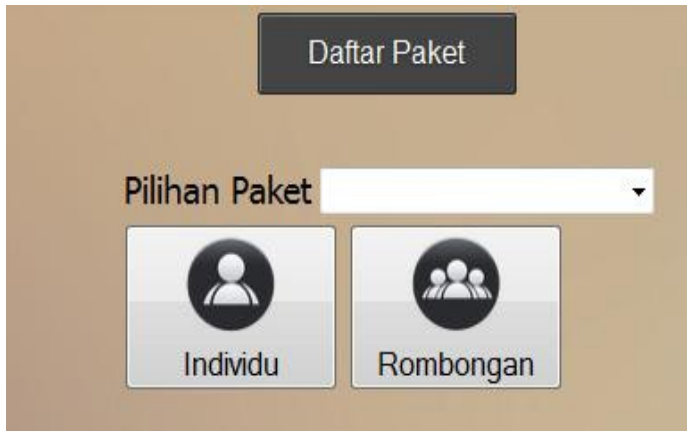

Gambar 13. Form registrasi Jamaah

Cara Kerja:

1. Tombol individu digunakan untuk menginput data jamaah umroh individu.

2. Tombol rombongan digunakan untuk menginput data jamaah yang melalui rombongan.

\section{Form Rombongan}

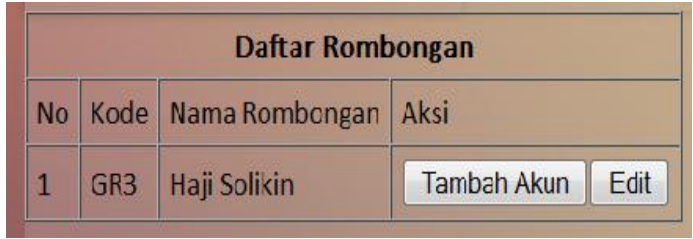

Gambar 14. Form registrasi Jamaah

Cara Kerja:

1. Tombol Tambah Akun digunakan untuk menambah akun.

2. Tombol Edit digunakan untuk mengedit data rombongan.

\section{Halaman Transaksi}

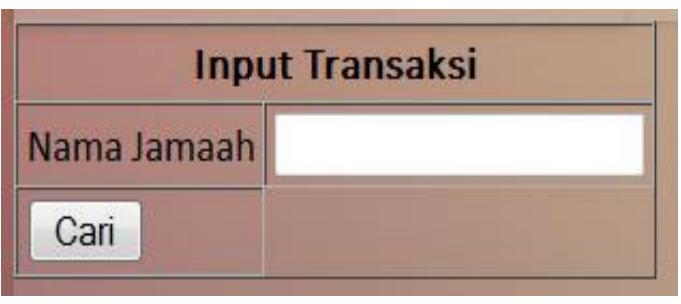

Gambar 15. Halaman Transaksi

\section{Form Transaksi}

\begin{tabular}{|c|c|c|}
\hline \multicolumn{3}{|c|}{ Transaksi Biaya } \\
\hline Kode Transaksi & \multicolumn{2}{|l|}{ TRIDV-10 } \\
\hline Nama Jamaah & \multicolumn{2}{|l|}{$A D$} \\
\hline Nama Paket & \multicolumn{2}{|c|}{ UMROH REG } \\
\hline Biaya & \multicolumn{2}{|l|}{881988} \\
\hline Status & \multicolumn{2}{|c|}{ BELUM LUNAS } \\
\hline \multicolumn{3}{|c|}{ Daftar Riwayat Pembayaran } \\
\hline \multicolumn{2}{|c|}{ Tanggal Pembayaran } & Nominal \\
\hline \multicolumn{3}{|c|}{ Tidak Ada Riwayat Pembayaran! } \\
\hline \multicolumn{2}{|c|}{ Total } & \\
\hline \multicolumn{2}{|l|}{ Kurang } & 881988 \\
\hline Transaksi & \multicolumn{2}{|l|}{ Kembali } \\
\hline
\end{tabular}

Gambar 16. Gambar Form Transaksi

Cara Kerja:

1. Tombol transaksi digunakan untuk melakukan transaksi pembayaran.

2. Tombol Kembali digunakan untuk kembali ke halaman transaksi.

\section{Halaman Laporan Jamaah}

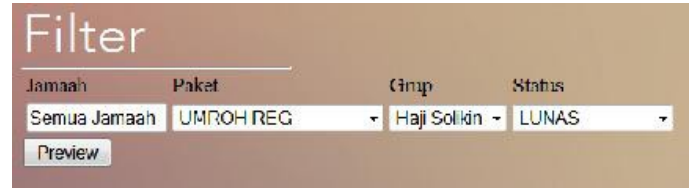

Gambar 17. Gambar Halaman Laporan Jamaah

Cara Kerja:

Tombol preview digunakan untuk mencetak data jamaah yang telah disaring maupun tidak. 


\section{Halaman Laporan Biaya}

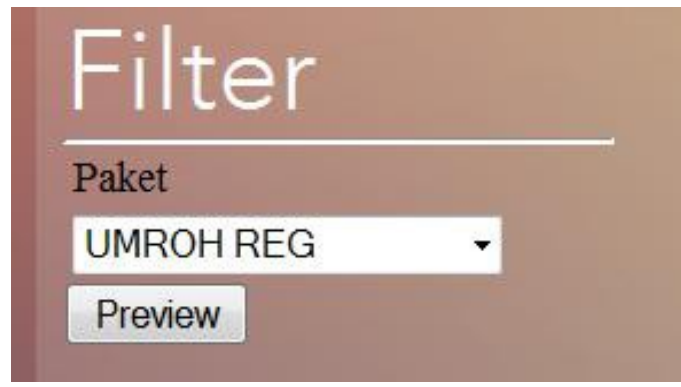

Gambar 18. Gambar Halaman Laporan Biaya

Cara Kerja:

Tombol preview digunakan untuk mencetak data paket setelah melakukan pemilihan paket umroh.

\section{Laporan Data Jamaah Umroh}

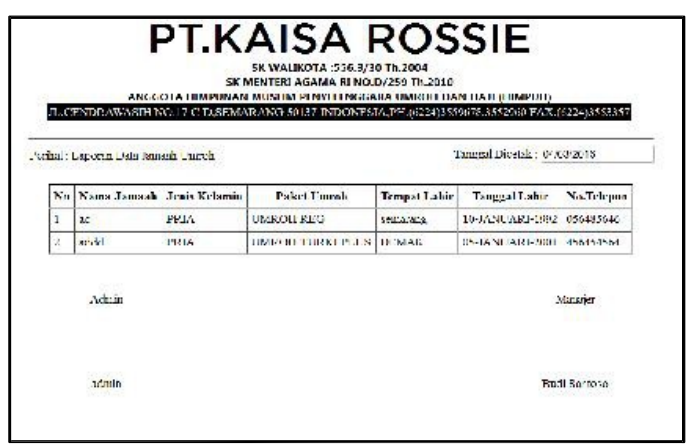

Gambar 19. Gambar Laporan Jamaah

\section{Laporan Biaya Paket Umroh}

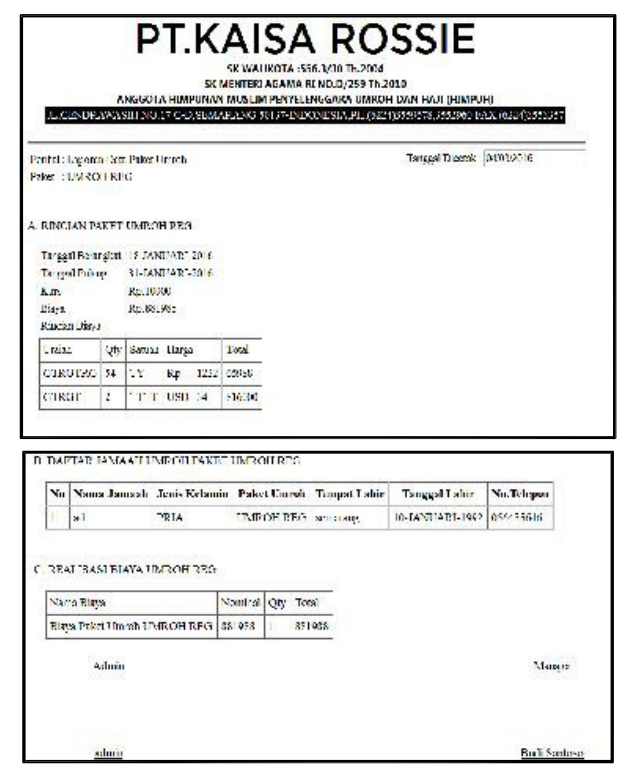

Gambar 20. Gambar Laporan Biaya

\section{Laporan User}

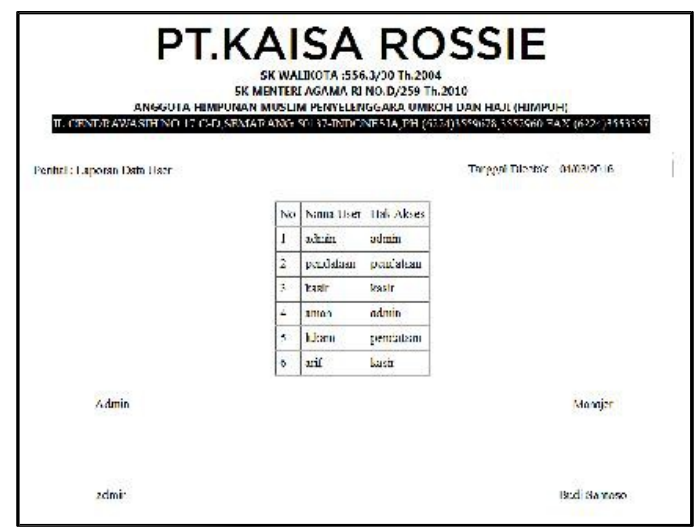

Gambar 21. Gambar Laporan User

\section{SIMPULAN}

Dari penelitian yang dilakukan oleh penulis menghasilkan beberapa kesimpulan sebagai berikut:

1. Program Aplikasi Data Jamaah Umroh Berbasis Web Dengan Metode Interpolation Search dikatakan layak kerena efisien dan akurat dari pada dengan sistem yang lama.

2. Aplikasi Data Jamaah Umroh Berbasis Web Dengan Metode Interpolation Search ini membantu kasir dalam proses pembayaran biaya umroh.

3. Penyampaian laporan dapat diditampilkan sesuai tanggal yang diinginkan (up to date).

4. Aplikasi Data Jamaah Umroh Berbasis Web Dengan Metode Interpolation Search memiliki lembar validasi desain oleh pakar dan validasi produk oleh user sehingga dapat membantuk produk yang dibuat penulis menjadi lebih baik.

\section{DAFTAR PUSTAKA}

Anhar. (2010). Panduan Menguasai PHP \& Mysql Secara Otodidak. Jakarta: Media Kita.

Bunafit. (2010). Panduan Lengkap Menguasai Perintah SQL. Yogyakarta: Mediakita.

Dhanta, R. (2009). Pengantar Ilmu Komputer. Surabaya: Indah.

Hendrayudi. (2008). VB 2009 Untuk Berbagai Keperluan Pemrogram. Jakarta: Elex Media Komputindo.

Ibisa. (2009). Keamanan Sistem Informasi. Yogyakarta: Andi. 
Jogiyanto. (2009). Pengantar IImu Komputer. Surabaya: Indah.

KBBI. (2019, 11 27). KBBI Daring. Diambil kembali dari https://kbbi.kemdikbud.go.id/: https://kbbi.kemdikbud.go.id/entri/Pen carian

Luth, T. (2004). Syariat Islam Tentang Haji dan Umroh. Jakarta: Rineka Cipta.

Munir, R. (2008). Belajar IImu Kriptografi. Yogyakarta: Andi.

Rachimi, M. A. (2012). Segala Hal Mengenai Haji dan Umroh. Jakarta: Erlangga.

Riyanto. (2014). Membuat Aplikasi Web dengan PHP dan Database Mysql. Yogyakarta: Gava Media.

Sabiq. (Buku Pengantar Teknologi Informasi). 2012. Jakarta: Bumi Aksara.

Sibero, A. F. (2011). Kitab Suci Web Programming. Yogyakarta: Mediakom.

Sugiyono. (2011). Metode Penelitian Kuantitatif Kulitatif dan R\&D. Bandung: Alfabeta.

Sutarman. (2012). Buku Pengantar Teknologi Informasi. Jakarta: Gramedia Pustaka Utama.

Yehefizar. (10 Jam Menguasai Komputer). 2008. Jakarta: PT.Elex Media Komputindo. 